\title{
Ovarian ultrasonography highlights precision of symptoms of ovulation as markers of ovulation
}

In recent years increasing interest has focused on the symptoms that accompany normal ovulation. ${ }^{.}$Identifying the accuracy of these symptoms as indicators of ovulation is of practical importance both to the subfertile couple trying to maximise the chance of conception and to the couple using "natural family planning" to prevent conception. Until recently it has not been possible to assess the accuracy of the symptoms because of difficulties in assessing the exact time of ovulation. Ovarian ultrasonography has now been shown to allow accurate observation of Graafian follicular growth up to the day of ovulation. ' 2 We therefore studied the exact relation between the major symptoms of ovulation and ovulation itself.

\section{Subjects, methods, and results}

We studied 15 menstrual cycles in six normal parous volunteers (age 25-42) who had been trained in observing ovulation symptoms for the purposes of natural family planning. They recorded their cervical mucus characteristics, basal body temperature, and other subjective data on standard forms. Follicular cultural World Health Organisation study did, however, show that over $90 \%$ of women, from all socioeconomic backgrounds, easily recognised the changing patterns of cervical mucus. ${ }^{1}$ Nevertheless, awareness of, and confidence in, these symptoms and their use for avoiding and achieving conception remains limited. One reason may be scepticism about their accuracy as precise markers of ovulation.

Our results raise the possibility that by identifying the day of most abundant fertile type mucus women can accurately pinpoint the day of ovulation with almost the same precision as luteinising hormone measurement. This knowledge could be used to maximise the chance of conception in subfertility. Furthermore, the last day of fertile type mucus occurred on or after the day of ovulation in all cases. This confirms this day as a good reference point for identifying the beginning of the post ovulatory infertile phase (currently taken as four days later ${ }^{1}$ ).

As the ovum survives for only 12-24 hours after ovulation our findings support the suggestion that when natural family planning methods fail this is due not to their unreliability but to user failure. The motivation of couples in

Day of luteinising hormone peak and symptoms of ovulation in relation to the day of ovulation as detected by ultrasound

\begin{tabular}{|c|c|c|c|c|c|c|c|}
\hline \multirow[b]{2}{*}{$\begin{array}{l}\text { Cycle } \\
\text { No }\end{array}$} & \multirow[b]{2}{*}{$\begin{array}{l}\text { Cycle } \\
\text { length } \\
\text { (days) }\end{array}$} & \multirow[b]{2}{*}{$\begin{array}{c}\text { Day of } \\
\text { ovulation } \\
\text { (ultrasound) }\end{array}$} & \multicolumn{5}{|c|}{ No of days from day of ovulation of: } \\
\hline & & & $\begin{array}{c}\text { Peak } \\
\text { luteinising } \\
\text { hormone }\end{array}$ & $\begin{array}{c}\text { Most abundant } \\
\text { fertile } \\
\text { type } \\
\text { mucus }\end{array}$ & $\begin{array}{c}\text { Last day } \\
\text { of fertile } \\
\text { type } \\
\text { mucus }\end{array}$ & $\begin{array}{c}\text { Day before } \\
\text { basal body } \\
\text { temperature } \\
\text { rise }\end{array}$ & $\begin{array}{c}\text { Last day of } \\
\text { periovulatory } \\
\text { pain }\end{array}$ \\
\hline 1 & 34 & 20 & $-1,0$ & 0 & 0 & 0 & 0 \\
\hline 2 & 34 & 20 & 0 & +1 & +1 & +1 & +2 \\
\hline 3 & 44 & 29 & 0 & NA & +1 & 0 & -2 \\
\hline 4 & $\mathbf{P}$ & 15 & 0 & 0 & +1 & 0 & -1 \\
\hline 5 & 33 & 16 & 0 & 0 & 0 & 0 & 0 \\
\hline 6 & 30 & 16 & 0 & -1 & +1 & 0 & 0 \\
\hline 7 & 28 & 13 & 0 & 0 & 0 & 0 & 0 \\
\hline 8 & 30 & 13 & NA & 0 & 0 & +2 & NP \\
\hline 9 & 28 & 14 & -1 & NA & +1 & +1 & NP \\
\hline 10 & 30 & 14 & 0 & 0 & +1 & 0 & 0 \\
\hline 11 & 33 & 17 & 0 & 0 & +1 & +1 & +1 \\
\hline 12 & 29 & 19 & 0 & NA & +2 & 0 & +2 \\
\hline
\end{tabular}

$\mathrm{P}=\mathrm{A}$ planned pregnancy occurred in this cycle following intercourse on day $15 . \mathrm{NA}=$ Not available. $\mathrm{NP}=$ No periovulatory pain.

development and ovulation were monitored by the full bladder technique described by Hackeloer et al ${ }^{2}$ using a Hitachi Tomosonic EUB $25 \mathrm{M}$ real time scanner. The maximum follicular diameter in each ovary was measured and the dominant follicle identified and photographed. Monitoring was continued each day until two days after the appearance of the corpus luteum. All ultrasonography was carried out by one operator (JD) and he and the women were blind to each other's findings, including menstrual dates. Daily samples were taken for periovulatory serum luteinising hormoie assessment (radioimmunoassay)

The ultrasound data on three of the cycles suggested persistent luteinised unruptured follicles. In the remaining 12 cycles the day of ovulation was taken as the day before the appearance of the corpus luteum on ultrasound. In nine of these cycles, as well as recording the standard markers of ovulation, ${ }^{1}$ the women recorded the day of most abundant fertile type mucus (having the characteristics of raw egg white ${ }^{1}$ ). In three cycles, however, this day was not marked because the women stated that, although a "most abundant day" had occurred, they had not recorded it as it was not part of their normal natural family planning routine.

Luteinising hormone concentrations were measured in 11 cycles. In nine there was a single peak value which coincided with the day of ovulation (see table). The day of most abundant fertile type mucus pinpointed ovulation with similar precision. The table shows that in the nine cycles when this was recorded it occurred on the day of ovulation (as determined by ultrasound) in seven. The last day of fertile type mucus, previously considered to be the most accurate marker of the day of ovulation, occurred one or two days after ovulation in eight out of 12 cycles and on the day of ovulation in only four. The day before the rise in basal body temperature coincided with the day of ovulation in eight cycles but occurred later in the rest. Pain, when it occurred, was the most insensitive marker, occurring anywhere over two days on either side of ovulation.

\section{Comment}

It could be argued that the women studied, as users of natural family planning, were not representative of the general population. The cross avoiding intercourse during the fertile days thus plays a major part in failure rates. This motivation, or lack of it, perhaps explains why the overall failure rates have varied from about zero in both Western ${ }^{3}$ and Third World cultures to as high as $25 \cdot 4 \%$ in one study. ${ }^{5}$

France JT. The detection of ovulation for fertility and infertility. In: Bonnar J, ed. Recent advances in obstetrics and gynaecology 14. Edinburgh: Churchill Livingstone, 1982: 215-39.

2 Kerin JF, Edmonds DK, Warnes GM, et al. Morphological and functional relations of Graafian Follicle growth to ovulation in women using ultrasonic, laporoscopic and biochemical measurements. Br $\mathcal{Y}$ Obstet Gynaecol 1981;88:81-90.

3 Roetzer J. Symptothermal methods of natural family planning. Intemational Review of Natura Family Planning 1981;5:200-2.

4 Ghosh AK, Saha S, Chattergee D. Symptothermia vis a vis fertility control. foumal of Obstetrics and Gynaecology of India 1982;32:443-7.

Wiessman MC, Foliaki L, Billings EL, Billings JJ. A trial of the ovulation method of family planning in Tonga. Lancet 1972;ii:813-6.

(Accepted 21 March 1986)

Department of Obstetrics and Gynaecology and Department of Medicine, University Hospital of Wales and University of Wales College of Medicine, Cardiff CF4 4XW

J DEPARES, MD, MRCOG, registrar in obstetrics and gynaecology

R E J RYDER, MB, MRCP, research fellow in medicine

S M WALKER, MB, FRCOG, senior lecturer in obstetrics and gynaecology

M F SCANLON, MD, MRCP, senior lecturer in medicine

Natural Family Planning Centre, Cardiff

C M NORMAN, BA, coordinator of natural family planning services

Correspondence to: Dr J Depares, Department of Obstetrics and Gynaecology, Clarendon Wing, General Infirmary, Leeds LS2 9NS. 